\title{
The Development of International Law in the Field of Renewable Energy*
}

\author{
Imam Mulyana \\ Faculty of Law, Padjadjaran University \\ Cluster Pawenang No. A15, Bandung, 40132, West Java, Indonesia. \\ Tel./Fax.+62-22-2508514 E-mail mulyana1982@gmail.com \\ Submitted: Nov 10, 2015; Reviewed: Jan 18, 2016; Accepted: Jan 24, 2016
}

\begin{abstract}
Energy plays a pivotal role in ensuring economic growth, social equity and live-able environment. In this regard, the non-renewable or conventional source of energy such as oil, gas and coal continue to supply the energy demand throughout the world. Nevertheless, as the awareness of the international society towards the protection and preservation of the global environment is rapidly growing, the utilization of energy resources has been gradually shifted from the non-renewable to renewable ones. Observing the international developments in the field of energy, further international legal instruments is required to be able to regulate renewable energy activities undertaken by the countries today. Although there have been a number of rules in international law, but until recently, most of these regulations is still not legally binding. Moreover, to achieve world order that uses renewable energy, international law also had to resolve some fundamental issues, namely the issue of state sovereignty and energy security.
\end{abstract}

Keywords: Energy Security; International Law; Renewable Energy; State Sovereignty

DOI: http://dx.doi.org/10.20956/halrev.v1n1.213

\section{INTRODUCTION}

The World Bank has given a limit on the standard of the basic needs that should be enjoyed by every human being, i.e food, water, shelter, health, education and employment. From these basic needs, energy is not directly mentioned (regarded as part of the food, where chemical energy from food can help the body function), but to enjoy all kinds of such basic needs, the human being requires energy. In the context of the mankind, there is a clear link between energy and social welfare, whereas in the context of economic and trade, energy called a very important factor of production. ${ }^{1}$ In short,

\footnotetext{
Mathhew Lach and Sandip Deshmukh, Sustainable Energy Law and Policy on Karen E. Makuch \& Ricardo Pereira (Ed.). (2012). Environmental and Energy Law. UK: Blackwell Publishing Ltd, p. 120
}

\footnotetext{
This article is part of Unggulan Research Faculty of Law Padjadjaran University entitled, "Model Kebijakan Dan Regulasi Sumber Daya Energi Laut Terbarukan (Marine Renewable Energy) Di Indonesia: Suatu Studi Pendahuluan”, which funded by the Faculty of Law Padjadjaran University, Indonesia.
} 
the energy in its various forms (mechanical, chemical, electrical, heat, electromagnetic radiation) has an important role in human life and is closely related to almost all the social issues. The relationship between man and the energy could be a relationship of quality and quantity, or a relationship about how humans get it, and then it can have an impact on social issues. ${ }^{2}$

The importance of energy has encouraged increased cooperation at regional and international levels. In the context of international cooperation, a wide range of cooperation related to the exploration and exploitation of energy have been made and agreed upon among countries in the world, ranging from fossil-based energy to use energy derived from nuclear power. ${ }^{3}$ Within the framework of regional cooperation, the importance of energy has prompted the establishment of one of the leading regional organization, the European Communities. Two of three agreements as basic to establish the European Communities are agreements on energy, i.e the European Coal and Steel Community Treaty and the Euratom Treaty. ${ }^{4}$ This shows that energy has a very important role in international and regional cooperation.

Although, energy is essential for human life, but the impact of today's energy

\footnotetext{
Jose Goldemberg, Development and Energy, on Adrian J. Bradbrook et. al. (2005). The Law of Energy for Sustainable Development, IUCN Academy of Environmental Law Research Studies, UK: Cambridge University Press, page. 37

3 The International arrangement in the field of energy related to the various of branch in the international law, energy rules can be seen among others, at http://www. ecolex.org/start.php, and https://www.wto.org/english/ tratop_e/envir_e/envir_neg_mea_e.htm.

$4 \quad$ Saleh Mothana Obadi and Matej Kortek. (2012). "The Analysis of Natural Gas and Crude Oil Market from the Global and EU Perspective", Studia Commercialia Bratislavensia Journal, 5(18), page. 228
}

consumption has led to the global warming and extreme climate change. One of the main causes of global warming and climate change which occurred in almost the last fifty years is the increased greenhouse gas emissions are $80 \%$ the amount resulting from human consumption of the fossil-based energy. ${ }^{5}$ The International Energy Agency (IEA) noted that the world's need for fossil-based energy will increase by at least $50 \%$ by 2030 with India and China as the countries that most contributes to the largest number on the rise in world energy demand. ${ }^{6}$

The impact of global warming and climate change is feared will provide a serious threat to human life. If not taken seriously, it is feared there will be an increase in sea levels ranged between 0.8 to 2 meters in $2100 .^{7}$ The increase in the sea level will not only melt glaciers and ice in the pole, but also lead to rising sea temperatures. The Intergovernmental Panel on Climate Change (IPCC) report that there was an increase in sea water temperatures between $0.36^{\circ} \mathrm{C}$ to $0.6^{\circ} \mathrm{C}$ in the late nineteenth century. In 2009, the forum of Climate Change Science Compendium 2009 was initiated by the United Nations Environment Programme (UNEP) submitted that the impact of climate change has been more rapid than the data submitted by scientists before, even forum also concluded there has been a change to the ecosystem on earth and recommended

\footnotetext{
Abdelkader Allali et al (eds). (2007). Climate Change 2007: Synthesis Report. UK: Cambridge University Press, page. 30

6 Mathhew Lach and Sandip Deshmukh, Op.Cit., page. 121

7 C.P. McMullen and J. Jabbour. (2009). "Climate Change Science Compendium" Available online from: http://www.unep.org/pdf/ccScienceCompendium2009/ cc ScienceCompendium2009 full en.pdf, accessed on 14 March 2015, at. 19.40.
} 
to immediately take preventive measures before changes in ecosystems becomes more distant and uncontrollable. ${ }^{8}$

In simple terms, the increase in sea water can start causing sinking small islands, increased storm activity, and may even have an impact on food security, water and sanitation problems. If the impact is very severe, it can also impact the massive migration, thereby potentially threaten world peace and security. ${ }^{9}$

In an effort to prevent global catastrophe, scientists have agreed, that the global temperature do not rise exceed $2^{\circ} \mathrm{C}$ in 2050 , then emissions of greenhouse gases must achieve its peak between 2017 to 2020 and then slowly decline until $2050 .{ }^{10}$ Despite this scientific fact has become common secret, but global efforts to decarbonization of energy by 2050 does not seem to get a serious response from countries, but concerns about the impact of energy use by humans should have made the countries launched the existence of a movement "energy revolution" globally. ${ }^{11}$

Efforts to mobilize international cooperation in terms of energy utilization reform actually began in 1987, through the Bruntland Report issued by the World Commission on Environment Development. Although not directly mention the energy reform, but the Brundtland Report has introduced the term "untapped potential energy", which should be the foundation in the development of en-

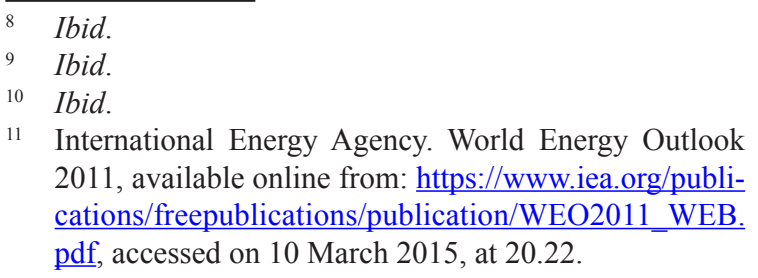

11 International Energy Agency. World Energy Outlook 2011, available online from: https://www.iea.org/publications/freepublications/publication/WEO2011 WEB. pdf, accessed on 10 March 2015, at 20.22.

ergy policy in the $21^{\text {st }}$ century. ${ }^{12}$ The peak of an international effort to reform the usage policy in 2012. The UNs' General Assembly declared the year 2012 as "International Year of Sustainable Energy for All" (SE4ALL). ${ }^{13}$ Furthermore, in order to strengthen the General Assembly resolution on this SE4ALL, UNs' Secretary General Ban Ki-moon has set a number of performance targets by 2030, among other things: ${ }^{14}$ 1) Open access is universal in terms of energy services; 2) Accelerate efforts to improve energy efficiency; and 3) Accelerate the utilization of renewable energy in the world energy mix from $15 \%$ to $30 \%$.

The utilization of renewable energy sources is not a maximal attempt in reforming the energy policy of the world, but the utilization of renewable energy sources is regarded as the approach most lenient in implementing the reforms and the use of energy on an international scale, especially converts energy utilization of fossil-based to energy based on renewable resources.

Based on the data, the utilization of renewable energy will decentralize and decarbonizes the electricity usage to 1.3 billion people on earth who today live without electricity. In addition, the utilization of renewable energy sources will be the alternative energy sources are considered prospective and able to replace dependence of

12 Marco Citelli, Marco Barassi, Ksenia Belykh. (2014). "Renewable Energy in International Arena: Legal Aspects and Cooperation", Groningen Journal of International Law, 2(1), page. 2

13 UN General Assembly Resolution 65/151 "International Year of Sustainable Energy for All" Available online at: http://www.un.org/ga/search/view_doc.asp?symbol=A/ RES/65/151

14 'Sustainable Energy for All: A Vision Statement by Ban Ki-moon, Secretary-General of the United Nations' (United Nations, November 2011) page. 4 
2.7 billion people today rely on fossil-based energy. The Intergovernmental Panel on Climate Change today encouraging the use of renewable energy resources, in the hope that by 2035 energy renewable resources can reduce greenhouse gas emissions by $21 \%$ and supply $45 \%$ of global electricity needs, for further in 2050 to supply $77 \%$ the world's need for electricity. ${ }^{15}$

\section{ANALYSIS AND DISCUSSION}

International Law in the Field of Renewable Energy

The history of international law noted that before 1945, the natural resources (including energy) is not an object of study that systematically studied in international law (with the exception of the arrangement in the field of fisheries and international rivers), but the development of the concept of sovereignty permanently to the natural resources, and the development of the law of the sea have made the birth of the law of natural resources as a new branch of international law. ${ }^{16}$ After 1945, the future of international law in the field of natural resources further the subject of discussion in various forums and influencing the policy makers and lawmakers, mainly deals with the issue of environmental damage threat caused by the exploration and exploitation of natural resources. ${ }^{17}$

Attention countries on environmental issues further developed after their attention

\footnotetext{
15 International Energy Agency, "Energy for All: Financing for the Poor," October 2011. The document downloadable on: http://www.iea.org/papers/2011/weo2011 energy for_all.pdf

16 Ricardo Pereira, The Exploration and Exploitation of Energy resources in International Law, on Karen E. Makuch \& Ricardo Pereira (Ed.). (2012). Environmental and Energy Law. UK: Blackwell Publishing Ltd., page. 199

17 Ibid.
}

to the issue of environmental damage caused by the exploration and exploitation of natural resources, particularly damage to the crossborder nature. These issues are growing in the realm of international environmental law. Development of international law in the field of the environment is evident in the Phillippe Sands' statement:

"...the international community's recognition that environmental problems transcend national boundaries has resulted in the development of an important new field of public international law. $^{18}$

At the beginning of its development the international environmental law only specifically related to certain things, such as the conservation of flora and fauna, especially those that are under the protection of the International Union for the Conservation of Nature (IUCN). Today, the International environmental law has evolved regulate various fields, including river and marine pollution, transport and waste disposal management of cross-border, as well as the emission of waste gases from the transportation and industrial sectors into the atmosphere. All these examples are all related to the energy sector. $^{19}$

Today, it appears that international law, international environmental law and energy law, to work together in making various kinds of regulations related to the energy sector. International law guarantees that every state has sovereignty over its natural resources so as to have the right to conduct exploration and exploitation of natural re-

\footnotetext{
18 Patricia Park, Op.Cit., page. 3

$19 \quad$ Ibid. page. 43
} 
sources, while the treaty in the field of international environmental law governing the types of energy policies adopted by countries in world, both collectively and individually. ${ }^{20}$

Most arrangement in the field of energy formally stipulated in international treaty, which form a written statement between the state and the state, or between states with international organizations. Even though the treaty-based arrangement, but this area is also governed by the customary law and the soft law. Institutions that makes international treaties, among others, international organizations (primarily the UN and the EU) with countries both bilaterally and multilaterally. Countries and international organizations also made customary law. The soft law is usually born from the international organizations. $^{21}$

\section{Institutional Development}

UNs' role in making international policy and establishing international bodies that regulate the activity of the countries in the field of energy appears prominent. Once over, the UN consists of six main organs, namely the General Assembly, the Security Council, the Trusteeship Council, the SecretariatGeneral, Economic and Social Council, as well as the International Court. These organs have issued a wide range of policies in the field of energy in accordance with their respective mandates. One of the most major concern of United Nations activities in the energy sector is fossil-based resource con-

20 Ibid.

21 See: Joseph F.C. Di Mento. (2003). The Global Environment and International Law. USA: The University of Texas Press, page. 17. servation and efforts to encourage the use of new energy resources and renewable. ${ }^{22}$ The $\mathrm{UN}$ is also very concerned about aspects of resilience and energy supply, including an analysis of the energy needs in the present and the future. More than twenty years, the UN has developed environmental standards that are binding, primarily the Principle 21 of the UNs' Conference on the Human Environment. ${ }^{23}$

The UN's General Assembly took the role in adopting resolution on permanent sovereignty over natural resources. In the UNs' Conference on Environment and Development in Rio Janeiro, the General Assembly encourages the Nairobi Programme of Action for the Development and utilization, and New and Renewable Sources of Energy. The General Assembly also give a review of the reports from the International Atomic Energy Agency (IAEA) and adopted a number of resolutions relating to the setting of nuclear energy, while the Security Council take on the role of the issues in the energy sector related to international peace and security. ${ }^{24}$

\section{United Nations Environment Pro-} gramme (UNEP) to encourage the development of research in the field of environment and systems in line with the standards issued by the United Nations. Under UNEP estab-

\footnotetext{
22 Patricia Park, Op. Cit., page. 14.

23 The United Nations Conference on the Human Environment, Stockholm, from 5 to 16 June 1972, Principle 21: "States have, in accordance with the Charter of the United Nations and the principles of international law, the sovereign right to exploit their own resources pursuant to their own environmental policies, and the responsibility to ensure that activities within their jurisdiction or control do not cause damage to the environment of other States or of areas beyond the limits of national jurisdiction."

24 Patricia Park, Op. cit., page. 15
} 
lished six divisions including one of which is the Division of Technology, Industry and Economics in which the focus of researching the Energy and Ozone Action Unit with the main objective to make energy management more effective and make policy planning in the energy sector. Other organs of the United Nations related to the energy sector is the International Maritime Organization (IMO) is one mandate is to realize the sea is safe and clean of all pollution. With the continued exploration and exploitation of oil and gas in the continental shelf of a coastal state and transport by tankers, IMO is responsible for establishing a number of rules as well as to monitor the implementation of these rules in the energy sector. ${ }^{25}$

The UN also established the IAEA with the obligation to report to the General Assembly and the Security Council in certain situations. The main task of IAEA is to ensure the use of nuclear energy for peaceful purposes, the development of health and welfare for mankind. The IAEA prohibit the use of nuclear to war. ${ }^{26}$ Especially for renewable energy, so in order to realize the creation of renewable energy use internationally would also require the involvement of various stakeholders. A number of international actors other than states, in particular international organizations, have been actively involved in the development of renewable energy in various fields, both within the regional and international scope.

At the international level, the $\mathrm{UN}$ is seriously continues to promote and encourage the use of renewable energy. The UN has made more than 40 separate programs related

25 Ibid.

26 Ibid. to the energy development, and invested 16 million US dollars to researching energy development, and specifically allocates 4 million US dollars for the development of renewable energy. ${ }^{27}$

Development actors besides the state covers its scope expanding, including development actors such as international NGOs (working in the field of renewable energy and energy efficiency), conferences and international forums (forums of international energy, the Group of Twenty Finance Ministers and Central Bank Governors, and the G8), international organizations (IRENA, OECD, International Energy Agency) and UN's agencies (UN Energy, UN Environment Programme, UN Development Programme, and World Bank). Today, the International Financial Institutions have also been specifically plays an important role in the transition process towards the establishment of low carbon energy policy, especially in the form of financial support. ${ }^{28}$

The development of institutional aspects in the management of renewable energy began to look at the Bonn conference in 2004. International Renewable Energy Conference (IREC) is the first in Bonn attended by around 154 countries. The conference was considered a historic moment where nations come together to achieve a common goal, namely the development of sustainable energy. ${ }^{29}$ Also, the conferences advocate and

\footnotetext{
$27 \quad$ Ibid.

28 Stuart Bruce. (2013). "International Law And Renewable Energy: Facilitating Sustainable Energy For All?", Melbourne Journal of International Law, Vol. 14, June, 2013, page. 24.

29 Read Janet L. Sawin, Mainstreaming Renewable Energy in 21st Century, World Watch Paper, 2004, downloadable on: http://www.worldwatch.org/system/files/ EWP169.pdf.1
} 
contribute to the development of renewable energy policy to the domestic level by enhancing attention and facilitation of policy change and technology transfer. Explicitly, the conference declared that: $:^{30}$

\begin{abstract}
Ministers and Government Representatives from 154 countries... acknowledge that renewable energies combined with enhanced energy efficiency, can significantly contribute to sustainable development, to providing access to energy, especially for the poor, to mitigating greenhouse gas emissions, reducing harmful air pollutants, thereby creating new economic opportunities, and enhancing energy security through cooperation and collaboration....
\end{abstract}

[A]gree to build upon the results and agreements reached at the Earth Summit ... the Millennium Declaration and the Millennium Development Goals ... and the World Summit for Sustainable Development ... reaffirm their commitment to substantially increase with a sense of urgency the global share of renewable energy in the total energy supply.

The Bonn conference gave birth to a mutual agreement to increase the amount of renewable energy in the total energy mix, and reaffirms the commitment of the parties to achieve the Millennium Development Goals (MDGs).

Furthermore, for the next years, also held a number of conferences with the same objective that is campaigning and promoting the use of renewable energy, among others in 2005 in Beijing (BIREC).$^{31}$ At the conference

\footnotetext{
30 See "Political Declaration" of 4 June 2004, Paragraph 1 dan 2, the document can be downloaded on http:// www.ren21.net/Portals/0/documents/irecs/renew2004/ Political declaration final.pdf.

31 Beijing International Renewable Energy Conference (BIREC) held on Nov 7-8, 2005.
}

the participating countries expressed their commitment to implement the UN Commission on Sustainable Development (CSD). After Beijing, the conference continued in Washington (WIREC), in $2008^{32}$ and 2010 in New Delhi (DIREC). ${ }^{33}$ At a conference in 2013 in Abu Dhabi (ADIREC), 160 ministers welcomed the initiative of SE4ALL and declare that they will continue to encourage attempts to accelerate the use of modern energy is directed to the use of renewable energy, and improving energy efficiency. Also, the ministers is agreed to declare energy year with emphasis on the importance of renewable energy, increased use of renewable energy at national and international levels. ${ }^{34}$

In order to promote and facilitate international cooperation in the field of renewable energy, then in 2009, established the International Renewable Energy Agency (IRENA). ${ }^{35}$ As contained in the statute, IRENA has been given the exclusive mandate to promote and encourage the widespread use of renewable energy. As the center of the development of renewable energy technologies, the IRENA's task is wide, such as analysis and monitoring of renewable energy

32 Washington International Renewable Energy Conference (WIREC) held on March 3-6, 2008. In contrast to the conference previously, WIREC is not result any declaration.

33 Delhi International Renewable Energy Conference (DIREC) held on October 27-29, 2010.

34 Abu Dhabi International Renewable Energy Conference (ADIREC) held on January 15-17, 2013.

35 IRENA established in Germany on 26 January 2009 and begin effective on 8 July 2009. The establishment of IRENA is initiated by Herman Scheer, ex-president Eurosolar and the World Council for Renewable Energy. Scheer propose a draft Supplemental Protocol to the Nuclear Non Proliferation Treaty (NPT) 1 June 1970, called 'Renewable Energy Proliferation Treaty' (REPT), give mandate to the IRENA to promote and encourage the transfer of renewable energy and campaign efficiency in this energy sector, based on the subsidiary principle. 
policy, cooperation with government agencies and non-governmental organizations, providing advice and guidance to member countries related to many issues (e.g financing and technical standards) and to promote research and development activities through knowledge and technology transfer. ${ }^{36}$

As an organization, IRENA also coordinate with other organizations working in the field of energy, especially with agencies of the United Nations, this is done to avoid overlapping, mainly related to the mandate of the organization. In the statute, IRENA also gives place to the principles of the United Nations and pay tribute to the United Nations with regard to energy. From IRENA's mandate, no single agency under the United Nations that specializes in handling issues of alternative energy. UNEP has a general duty to assist developing countries in almost all environmental activities and provide advice and policies that are not only limited to climate change, but including also the development of environmental management and technology transfer for sustainable development.

Other agencies under the United Nations are the United Nations Development Programme (UNDP) focuses on the development and cooperation with poor countries, particularly in developing the capacity to develop policies in favor of environmental conservation. The United Nations Industrial Development Organization (UNIDO) encourages clean energy and sustainable

\footnotetext{
36 See Article IV, paragraph 1 letter a - $\mathrm{h}$ and paragraph 2, Statuta IRENA can be downloaded on http://www. irena.org/documents/uploadDocuments/Statute/IRENA_FC_Statute signed_in_Bonn_26_01_2009_incl declaration on further authentic versions.pdf.
}

energy use in the industrial and the agroeconomy sectors. ${ }^{37}$

The UN agency that may have similarities with IRENA's mandate is the IEA. Although the IEA has limited membership (only OECD), the IEA has a broad mandate. IEA's mandate includes, energy security, economic development through the supply of energy, to the setting of labor engaged in the field of energy. Renewable energy is not the focus of the IEA. Internationally known also Renewable Energy and Energy Efficiency Partnership (REEEP) and the Renewable Energy Policy Network for the $21^{\text {st }}$ Century (REN21), which specializes in the development of renewable energy. Nonetheless, REEEP and REN21 is a nongovernmental organization. IRENA itself has worked closely with REEEP and REN21 in order to develop renewable energy. As 27 January 2013, IRENA has consisted of 106 members, including the European Union and 54 countries signing.

Today, IRENA has become a leading organization that plays a role in bridging the intergovernmental dialogue, including to promote cooperation in renewable energy, develop technology and knowledge in the field of renewable energy, including the more important to encourage the state and the private sector to engage in cooperation in the development of renewable energy in accordance with scale and capacity respectively.

IRENA has published Nationally Appropriate Mitigation Actions Handbook ${ }^{38}$

37 Marco Citelli, Marco Barassi, Ksenia Belykh, Op. Cit., page. 27

38 The document can be downloaded on http://www.irena. org/DocumentDownloads/Publications/Handbook $\underline{\text { RE NAMAs.pdf }}$ 
to assist with the transition of energy derived from fossil resources into the production and consumption of renewable energy, encouraging Gulf countries to participate and discuss in order to develop policies at regional level associated with the development of renewable energy, even actively involved in shaping the Dubai Electricity and Water Company that develops renewable energy in Dubai, and subsequently formed the Global Atlas for Renewable Energy Resources. Today, IRENA has become an organization that does multilateral action, especially in order to promote and encourage SE4ALL.

\section{Arrangement Development}

Throughout related to international law, it can be said that until now the legal instrument that comprehensively governs still limited energy resources, both renewable or not. Regulatory instruments in the international scope that exists today is still largely scattered in various sectors, such as oil, natural gas, nuclear, and international trade related to the energy resources. Instruments of international law that specifically regulates only the energy contained in the Energy Charter Treaty (ECT) 1994, which initially focused on European countries, but the current membership has expanded to Japan, Australia and Mongolia. ${ }^{39}$

ECT regulates some things related to renewable energy. As contained in the Final Act of this document, the types of activities included in the economic activity in the energy sector also include "construction and

39 Energy Charter Secretariat, "The Energy Charter Treaty and Related Documents." Accessed on website: http:// www.encharter.org/fileadmin/user_upload/document/ EN.pdf Accessed on 26 March 2014), page. 19 operation of power generation facilities, including those generated by wind power and other renewable energy sources." ${ }^{40}$ In addition, ECT also encouraged States parties to specifically concerned with improving energy efficiency and the development and utilization of renewable energy resources in order to ensure sustainable development and environmental protection. ${ }^{41}$

Meanwhile, in the context of the activity of renewable energy in the sea, some of the provisions contained in the Convention of the United Nations on the Law of the Sea (United Nations Convention on the Law of the Sea) in 1982 (hereinafter referred KHL), can be used as a reference in encouraging countries to develop and exploit this type of energy. For example, the provisions of the KHL on sovereignty and jurisdiction of coastal States in the various maritime zones should be considered in terms of placement of the installation of marine energy utilization in these maritime zones. For example, installation of energy flows and hydro-kinetics is placed in the inland waters that are subject to the full sovereignty of the coastal State. ${ }^{42}$

If the installation of marine energy is placed in the exclusive economic zone (EEZ), then based on KHL, the coastal State has sovereign rights to explore and exploit natural resources, both biological and non-biological, including the activities of exploration and exploitation for other economic activities such as the use of energy

\footnotetext{
$40 \quad$ Final Act Energy Charter Treaty.

41 Article 19 paragraph (1) letter (d)

42 David Leary and Miguel Esteban. (2009). "Climate Change and Renewable Energy from the Ocean and Tides: Calming the Sea of Regulatory Uncertainty" Marine and Coastal Law, 24: 617-631.
} 
of water, currents and winds. ${ }^{43}$ In addition, the coastal State also has the exclusive right to establish, authorize and regulate the facility set up in order to take advantage of the resources contained in the EEZ. ${ }^{44}$

Of course, the rules are felt still less than adequate, especially to accommodate the activities of utilization of renewable energy are very spacious dimensions. Apart from the lack of rules in international law related to renewable energy sources, the development of sources of international law arrangement in the field of renewable energy at least can be categorized into two aspects of the development of sources of law, namely the development of sources of international law in the field of energy nonbinding nature (soft law) and international policy, and the development of relevant sources of international law which is binding (hard law). ${ }^{45}$

The Development of the Source of International Law are Soft Law and International Policy

The international community has grown increasingly dependent on sources of international law are not binding (soft law), primarily because of the many problems that is not easily addressed by traditional sources of international law (through instruments which are binding). In general, soft law refers to the obligations that are not legally binding or norms that include principles, policies and resolutions adopted by non-state actors.

Although debate continues about soft law and hard law in the international law,

43 KHL Article 56 paragraph (1) letter (a).

44 KHL Article 60 paragraph (1) letter (b).

45 Adopted from Stuart Bruce's writing, Op. cit. page 11. consciously or not, the role of soft law in the development of international law in the field of energy is very helpful, especially in playing the role of integrating the norm, expanding influence, and answer the problems in the field of energy quickly.

In addition, soft law is considered more advantageous to regulate the activities in the field of energy because they are more flexible and can adapt more quickly to follow the development of the energy world is loaded with technology that is very fast growing. ${ }^{46}$

Based on the time, at least four different approaches stages of soft law related to the development of international law in the field of renewable energy, namely:

a) The international law approach by using the general principles (1972 - 1991)

On 5-16 June 1972, held United Nations Conference on the Human Environment in Stockholm, Sweden. ${ }^{47}$ The conference then produced three nonbinding documents: (i) a document on institutional and financial arrangements; (ii) declaration that describes 26 principles; (iii) an action plan that provides 109 recommendations. Of the three documents, the most important is the 26 principles contained in the Declaration of Stockholm. The most concerned with the law is a Principle $21,{ }^{48}$ Principle $22,{ }^{49}$

46 Duncan French. (2005). International Law and Policy of Sustainable Development, UK: Juris and Manchester University Press, 2005, p. 37.

47 John O'Brien. (2001). International Law. London: Cavendish Publishing Limited, page. 662

48 This principle govern that states based on the United Nations' Charter and the principle of international law has sovereign rights to exploit their resources as their environmental policy, and has responsibility to ensure that activities in their jurisdictional is not causing damage of other country environment or area beyond the its country national jurisdictional boundary.

49 The mention of this principle that states must cooperate 
Principle $23^{50}$ and Principle $24 .{ }^{51}$

The legal experts argue that the position of the Stockholm Declaration in the field of environmental can hardly be said the same impact with the Universal Declaration of Human Rights in the field of human rights, because even though the documents created are not binding, but the Stockholm Declaration has changed the perspective of many countries to the problem environment as well as a guideline for countries in creating policies in the environmental field.

Briefly, Principle 1 of the Stockholm Declaration connecting quality of the environment and human rights, while the other principles set different goals. Principle 2, 3 and 5, emphasizing the importance of the protection of natural resources, while the principle 4, 6 and 7 , emphasizing the danger of a threat to the environment. Associated with the interests of developing countries, the Principle 8 to 15 govern the relationship between development and environmental protection, as well as the Principle 16 to 20 explain the principles related to the policies of demographic and population

to develop further international law, especially about obligation and compensation for pollution victim and environmental damage that caused by activity inside or outside of jurisdictional.

50 This principle confirms that without reduce criterion as agreed by the international community, or standard determined nationally, so consider the prevailing value systems in a country in a case is very required, this thing is likely due to the difference between develop and developing countries.

51 This principle explains that the action of international about protection and environment recovery must be handed in the spirit of cooperation by all countries, large or small, based on the equality principle. Cooperation through multilateral or bilateral cooperation or other ways as it is very important to control, prevent, reduce or eliminate the environmental impact that damage activities for all field effectively. growth. ${ }^{52}$

Stockholm Declaration can immediately feel the impact. With the encouragement of the General Court and the establishment of the United Nations Environment Programme, campaigns on the importance of environmental legislation system created both at regional and national level through multilateral treaty is more developed. ${ }^{53}$

After the Stockholm Declaration, emphasis on the importance of giving attention to the environmental aspects of development has affected all areas of policy. It can be seen from several developments, such as, the first, the international organizations began to show great concern, for example, in 1971 GATT established Group on Environmental Measures and International Trade. Second, at the regional level, for example, is an amendment to the Treaty of Rome in 1957 in Europe into the European Single Act 1986. Third, UNEP gave birth to "Principles of Conduct in the Field of the Environment for the Guidance of States in the Conservation and Harmonius utilization of Natural Resources Shared by Two or More States". Fourth, the efforts of UNESCO, FAO and WWF in 1980 held the World Conservation Strategy that tries to associate the importance of development and the environment and adopt the principle of "sustainable development".

Nonetheless, in this period, the most significant developments in the

\footnotetext{
52 John O’Brien, Op. Cit., page. 663

53 Ibid
} 
environmental field are when the 1987 World Commission on Environment and Development (WCED) issued its report. ${ }^{54}$ This report is considered a significant contribution in the field of environment because emphasizes the importance of looking at environmental issues as a complex issue involving many stakeholders to finish. Emphasizes the importance of public education on the impact of environmental damage, emphasizes the importance of legislation in the field of environment both at national and international levels. Emphasizing the need of accommodate the principle of "sustainable development" in the country's efforts to develop legislation in the environmental field. This report will then be one of the causes made General Assembly's Resolution to convene the United Nations Conference on Environment and Development which was then held in Rio, Brazil in June 1992. ${ }^{55}$

b) The International law approach through sustainable development (1992 - 2001)

United Nations Conference on Environment and Development (UNCED) held in Rio de Janeiro, on 3-14 June 1992. In conclusion, UNCED adopted three non-binding legal instruments are: (i) Rio Declaration on Environment and Development (Rio Declaration); (ii) Principles for a Global Consensus on the Management, Conservation and Sustainable Development of All Types of Forest (UNCED Forest Principles); and (iii) Agenda 21. At the same time also signed two treaties, namely: (i) Convention on Biological Diversity, (ii) United Nations Framework Convention on Climate Change. The Rio Declaration is considered more fully regulate environmental aspects compared to the Stockholm Declaration. Rio Declaration also promotes the importance of cooperation and the application of the principles of sustainable development in construction. In addition, UNCED also create a document known as Agenda 21, which contains an action plan to promote environmental concerns and development. ${ }^{56}$

c) The International law approach to the use of energy for sustainable development (2002-2010)

In 2002, for the first time a discussion of energy issues associated also with the issue of energy security, climate change and sustainable development. This year, starting discourse of countries to encourage renewable energy issues as a political agenda in each country. As a result, 90 of the 118 countries committed to implementing regulations and continue the development of policies at the domestic level in terms of renewable energy.

Further, the international treaty of this commitment is the Johannesburg Plan of Implementation (Johannesburg Plan). Johannesburg Plan has provided some guidance to countries associated with renewable energy, as follow: ${ }^{57}$
$54 \quad$ Ibid

55 Ibid
$56 \quad$ Ibid

57 See, Johannesburg Plan, UN Doc A/CONF.199/20. 
Develop and disseminate alternative energy technologies with the aim of giving a greater share of the energy mix to renewable energies ...

...with a sense of urgency, substantially increase the global share of renewable energy sour-ces with the objective of increasing its contribution to total energy supply.

With the mention of the term "renewable energy" as much as 12 times, the Johannesburg Plan regarded as "soft law" which openly support the development, implementation, commercialization and transfer of renewable energy technologies. $^{58}$ Although, the Johannesburg Plan be considered as a legal instrument to the target is not clear and does not regulate the principles that bind, but the Johannesburg Plan was to create awareness to the world about the importance of linking economic growth with environmental degradation. Even further, the Johannesburg Plan considered to have brought energy issues from the domestic level to the international level.

d) Approach to sustainable energy for all (2011-2030)

Although the UN's General Assembly can only make recommendations, but by the number of membership and its role in the development of international law, the General Assembly can make a significant contribution, particularly in determining the new norms of the new issues that evolve in internation-

58 Ibid. Johannesburg Plan, UN Doc A/CONF.199/20, Chapter I Section 2 annex, Article: 9(a), 9(c), $20(\mathrm{c}), 20(\mathrm{~d}), 20(\mathrm{e}), 20(\mathrm{~g}), 20(\mathrm{j}), 20(\mathrm{k}), 20(\mathrm{n}), 20(\mathrm{t})$, 59(b), 62(j) (ii). al law. One of the contributions that are considered important in the development of renewable energy is the declaration of 2012 as the International Sustainable Energy for All (SE4ALL).

The General Assembly considers the presence of global challenges, especially in the fields of energy, it is necessary to call for the transformation of energy, which is global appeal with clear targets mainly to increase the production and utilization of renewable energy. The appeal also demands action strategies to encourage policy from the domestic to the international level, although not binding, but this strategy has put renewable energy in a discourse of dialogue at the international level is more spacious. ${ }^{59}$

Sources of International Law that are Binding (Hard Law)

The development of international environmental regulation, particularly in the field of climate change, is an example of the development of the most excellent of how the world community to react collectively in responding to environmental issues. This regime has made a number of rules that are binding and set a number of obligations under several international treaties and the consequences associated with energy consumption which then impact on the atmosphere and the environment. ${ }^{60}$

Climate change regime began in 1988 , when the UN's General Assembly calling for climate change is an issue that should

59 UNGA Res. No. 65/151 "International Year of Sustainable Energy for All"

60 Crawford. (2012). Brownlie's Principles of Public International Law. UK: Oxford University Press, $8^{\text {th }} \mathrm{ed}$, p. 37-42. 
be concern together, so that in 1992 made the United Nations Framework Convention on Climate Change ("UNFCCC"). The moment of this UNFCCC mark international recognition that the production and use of fossil-based energy has an impact on climate change, and then seek a solution of the climate change crisis caused by the production and use of fossil-based energy.

Renewable energy has not been addressed in the UNFCCC. UNFCCC, then run framework for actions that aim to stabilize the concentration of greenhouse gases (GHGs) in the atmosphere to avoid dangerous global warming is more to life on earth. The convention itself became effective on March 21, 1994, the UNFCCC Convention has now been signed by 195 countries.

In December 1997, the $3^{\text {rd }}$ the Conference of the Parties (COP) approved Protocol of UNFCCC which binds industrialized countries and countries in transition to a market economy to achieve emission reduction targets. The $3^{\text {rd }}$ Conference of the Parties (COP) was held in Kyoto, Japan. Countries that agree to this, known as Annex I parties under the UNFCCC. Countries that adopt Annex I agreed to reduce their emissions of six greenhouse gases overall average of $5 \%$ below level 1990 during the period 20082012 (the first commitment period), with specific targets varying from country to other countries. To achieve this target, the Annex $B$ of the Kyoto Protocol requires countries to make policy at the domestic level. The only references to renewable energy in the Kyoto Protocol contained in article 2, paragraph (1) letter a, which advises the State party to conduct research, development, promotion and increased use of renewable energy. ${ }^{61}$

Although the Kyoto Protocol is still little mention of the obligations binding, but in practice this provision has been instrumental in reducing worlds' carbon dioxide $\left(\mathrm{CO}^{2}\right)$ almost equivalent of 45 million tons and to make countries began to devolving upon to the renewable energy use. Kyoto Protocol has also encouraged the mechanisms more flexible, such as in the development of energy-friendly, and encourages public private partnership in the development of renewable energy sources.

International law regime on climate change has grown rapidly, especially after the birth of the UNFCCC and the Kyoto Protocol. Some further developments seen in the discussion of issues of OCP, among others: ${ }^{62}$

1. The trial was held in Montreal, Canada, in late 2005, the first session of the Conference of the Parties serving as the meeting of the Parties to the Kyoto Protocol (CMP) decided to establish a working group ad-hoc on Further Commitments for Annex I Parties under the Kyoto Protocol (AWG-KP), regulate the implementation of the Kyoto Protocol (KP) post-2012.

2. The trial of $12^{\text {th }} \mathrm{COP}$ was held in Nairobi, Kenya in 2006, and discussed several things including: Further discussion of the climate change regime post 2012, the initiation of the Clean Development Mechanism (CDM) and Joint Implementation(JI), the formulation of the principles and modalities of the Adaptation Fund,

\footnotetext{
61 See Kyoto Protokol 1997.

62 The history of UNFCCC negotiation, the National Board of Climate Change, 2012.
} 
and the Special Climate Change Fund (SCCF) Indonesia, resulted in treaty on the Bali Roadmap.

3. $13^{\text {th }}$ COP adopted the Bali Action Plan (BAP) and established the Ad Hoc Working Group on Long-term Cooperative Action under the Convention (AWGLCA) with a mandate to focus on mitigation, adaptation, technology, finance, and a shared vision for long-term cooperative action.

4. The session 14 of the UN's climate change conference in Poznan, Poland was held in December 2008. At the meeting in Poznan was held simultaneously of the trial of $29^{\text {th }}$ SBI and SBSTA, the sixth meeting of the AWG-KP and the third meeting of AWG-LCA.

5. UN's Climate Change Conference in Copenhagen, Denmark, took place in December 2009. This negotiation resulted in a political treaty: "Copenhagen Accord," which was then submitted to the plenary meeting of the COP for adoption. The parties to the UNFCCCs' participants also agreed to extend the mandate of the AWG-LCA and AWG-KP until COP 16 and CMP 6.

6. UN's Climate Change Conference in Cancun, Mexico took place in November 2010. Decision 1/CP.16 recognizes the need for cuts in the global emissions to limit global temperature rise above $2{ }^{\circ} \mathrm{C}$. In Cancun, Nationally Appropriate Mitigation Actions (NAMAs) and NonAnnex I Marginal Abatement Cost curve (NAMAC) is also presented. The above decision is also takes into account other aspects of mitigation, such as: Monitor- ing, Reporting and Verification (MRV), and reducing emissions from deforestation and degradation in developing countries, including through conservation $(\mathrm{REDD}+)$.

7. UN's Climate Change Conference in Durban, South Africa, taking place from November 28 to 11 December 2011. The results of Durban include a variety of topics, especially the establishment of a second commitment period under the Kyoto Protocol, a decision longterm cooperative action under the Convention and the agreement on the operationalization of the fund green/ Green Climate Fund (GCF).

\section{The development of Renewable Energy} at the Regional and International Levels:

\section{Barriers and Challenges}

Various kinds of conferences that have been implemented by the countries in order to encourage the use of renewable energy in part have shown results, such as the commitment of countries in terms of determining the period of international cooperation and define targets to be achieved by each country.

The commitment is often stated in the declaration forms, policies, or other legal instruments that are not binding. On the other hand, the state has a tendency to selfbind to the legal instrument which is more binding, which can provide the settings to them directly about the renewable energy. The process of norms formation are more binding in practice occurs at regional level, which is actively facilitated by several countries. 
In the context of Eurasian countries, ${ }^{63}$ cooperation in the energy sector, particularly through trade and investment sectors have been set up by establishing a legal framework agreed. Beginning with the political declaration adopted in the European Energy Charter, the legal framework for the development of energy and then confirmed in the Energy Charter Treaty and in its protocol namely Protocol on Energy Efficiency. ${ }^{64} \mathrm{Ar}-$ ticle 19 ECT became one of the environmental setting that asks countries to reduce environmental degradation, promote sustainable development by means inter alia, improving energy efficiency, developing and utilization of renewable energy, encouraging the use of fuels that are environmentally friendly, as well as using technology to reduce pollution. Protocol further complements with a number of obligations, including obligations related to the development of laws, policies and regulations (Article 3), energy efficiency strategy (Article 5), and a number of programs (Article 8). ${ }^{65}$

ECT was made after the cold war as a non-binding instrument. The ultimate goal is to provide a legal basis and framework for enhancing the efficiency and integrated energy policy in Europe. Although, ECT accommodate extensive rights and obligations, but ECT itself is a sectoral energy policy.

63 Includes the countries members of European Communities (EC) and Commonwealth of Independent States (CIS) countries. CIS is countries have joined in the Uni Soviet, i.e Armenia, Azerbaijan, Belarus, Kazakhstan, Kyrgistan, Moldova, Rusia, Tajikistan, and Uzbekistan.

${ }^{64}$ European Energy Charter, 98/181/EC, 17 April 1991, the Hague (Netherlands); Energy Charter Treaty, 17 December 1994, Lisbon (Portugal); Protocol on Energy Efficiency, 17 December 1994, Lisbon (Portugal).

65 Protocol on Energy Efficiency. Document downloadable on: www.encharter.org/fileadmin/user upload/... texts/1994 PEEREA.pdf
In addition to ECT, other instruments that also drew attention to the link between energy and the obligations that impact on the environment is the Protocol on Energy Efficiency and Related Environmental Aspects (PEEREA). ECT does not create a separate protocol for each type of energy used in Europe, however, the issue of renewable energy discussion united in PEEREA.

Arrangements regarding energy sources contained in the ECT, among others in the "Economic Activity in the Energy Sector" regulates the construction and operation of energy facilities based on renewable energy. As a consequence, renewable energy to enter into the scope of energy set out in ECT. Other provisions regarding renewable energy contained in the ECT explicitly contained in Article 19 (1) (d) asking the parties to "have particular regard...to developing and using renewable energy sources' and to promote cleaner fuels."

In general, ECT also regulates the promotion of awareness of the environment damaged by the use of energy, human welfare and concern for the environment, research, development and application of technologies that minimize the destructive impact in the energy cycle. On development, ECT tries to combine traditional energy consumption arrangement and introduce arrangements regarding the renewable energy consumption. In further developments, the Secretariat of ECT create a task force to create a model of how to balance the rights and obligations under the treaties in full, regulating energy projects that are crossing borders, including treaties among government institutions and among the Presidents. Also, this model is 
regulate the activity of investors and has the objective to facilitate the relationship of power generation efficiency of crossborder transmission of energy to organize and provide regulatory aspects. And further, this model enters into the Renewable Energy Directive. ${ }^{66}$

Renewable Energy Directive encourages the use of renewable energy in the countries members and the European Union has set a number of targets that by 2020, the use of energy derived from renewable energy has reached $20 \%$ of the total energy mix in the EU. This directive also targets that the energy consumption of the countries members of the European Union, particularly energy in the field of transport should reach $10 \%$ of the energy consumption in the transport sector coming from renewable energy.

To achieve this target, the Renewable Energy Directive has made a number of targets which must be met by each countries members, the way is to require the use of renewable energy in the national energy mix of each countries members. Obligations at the national level are also encouraged to develop is to make regulations to provide legal certainty to investors and promoting technology development in the field of renewable energy development.

Each EU's countries members are then required to create a national plan that describes about their plans to achieve its goals respectively. This national plan must describe how the countries concerned to make use of renewable energy policy in the areas of transport, electricity, heating energy

66 See EU Renewable Energy Directive, document 2009/28/EC. even for household needs by 2020. Each country has the freedom to define the schema and forms of renewable energy will be developed, but each national policy in the field of energy should refer to the targets set by the secretariat. Progress reports must be submitted to the secretariat to be evaluated every two years. ${ }^{67}$

Each countries member can also apply to the secretariat of the financial assistance scheme to support the national plan of the renewable energy development in their respective countries. Renewable Energy Directive sets a series of target that must be achieved between all countries members up to 2020 , a number of intermediate targets are:

a) $25 \%$ of the targets to be achieved in 2020 should be achieved in 2011 and 2012;

b) $35 \%$ of the targets to be achieved in 2020 should be achieved in 2013 and 2014

c) $45 \%$ of the targets to be achieved in 2020 should be achieved in 2015 and 2016; and

d) $65 \%$ of the targets to be achieved in 2020 should be achieved in 2017 and 2018.

Directive specifies no fine financially, if a country cannot achieve the intermediate target. The Secretariat has the right to conduct the evaluation process and provides recommendations if there is a violation, especially when the state is not doing any necessary action to meet the targets that have been given.

\footnotetext{
67 Patricia Park. (2013). International Law for Energy and the Environment, $2^{\text {nd }}$ edition, Boca Raton US: CRC Press, page. 180-182.
} 
In an effort to meet their targets, one or more countries can work together on a joint project to produce renewable energy sources. They can also cooperate with countries outside the EU, even under certain conditions they can also do energy imports from third countries to meet the targets assigned to them. ${ }^{68}$ If the foregoing, the producers of renewable energy on a small scale considers that there is no transparency and limited access to compete in the procurement of renewable energy, the Directive ensures that the transmission and distribution of procurement of renewable energy should be opened in a transparent and accessible to all companies, small, medium and large scale. Countries members are also required to conduct an assessment of supporting infrastructures in each new district in their respective countries; especially the infrastructure used for domestic purposes, and shall then be submitted in the national plan. ${ }^{69}$

Although the arrangement of renewable energy at the regional level have been quite advanced, but the arrangement of international cooperation in the field of energy are not easy to achieve. If to achieve international cooperation in the field of the environment require a long time, the cooperation in the field of energy requires a longer time, especially cooperation in the field of renewable energy at sea. Nonetheless, efforts to develop international cooperation in the energy sector have evolved over the last decade, especially after the World Summit on Sustainable Development (WSSD) in $2002 .^{70}$ The development of cooperation

\footnotetext{
$68 \quad$ Ibid.

69 Ibid.

70 Stuart Bruce, Op.Cit., page. 10.
}

arrangements in the energy sector is further demanded international law to accommodate the interests of those countries involved and make rules to facilitate the development of this activity.

In facilitating the arrangement of renewable energy on an international level, international law faces a number of challenges. These challenges include concerns related to state sovereignty over natural resources and domestic policy of each country about energy security. In addition, the domestic energy policy of many countries today, still make fossil-based energy as the main source of the national energy mix. It can be seen from the amount of subsidies to fossil-based energy world which reached 400 billion US dollars, while the amount of subsidies to renewable energy world only reached 66 billion US dollars. ${ }^{71}$ The subsidy issue is closely linked to energy security issues, particularly the issue of price stability.

As described above, the legal issues seem to be a barrier in the development of renewable energy sources, particularly related to aspects of maritime law. It is composed of at least two issues, first is related to the issue of sovereignty, secondly related to readiness to facilitate the development of international law in the field of renewable energy, particularly in maintaining global energy security.

\section{State Sovereignty}

It should be the concern will be barrier in cooperation in the field of energy; in particular

\footnotetext{
71 International Energy Agency, World Energy Outlook 2011, page. 39. Available online at: http://www.iea.org/ publications/freepublications/publication/weo2011 web.pdf.
} 
the renewable energy is state sovereignty. In associated with the arrangement of energy activities in a country, there are at least three aspects of sovereignty are intertwined, namely: ${ }^{72}$ 1) The Internationalization of Essentially domestic matters; 2) Permanent sovereignty over natural resources; and 3) Principles of international environmental law, such as the "no harm" rule.

Permanent sovereignty over natural resources is inherent in every country, including in managing and utilization of natural resources of the country concerned as an energy source, and create rules that related to the management and utilization of natural resources.

Countries also have external sovereignty in the field of energy management, one form is to establish cooperation with other countries. Some international cooperation formed between India and Iran, for example, that India will flow gas from Iran which has one of the world's gas reserves. China provides investment loan of US\$4050 billion for infrastructure development in Nigeria in the hope of gaining access to the oil fields in Nigeria, Japan, Korea and the countries of consumers in general are also working in the field of energy by relying on economic strength, finance and technology. ${ }^{73}$

In the context of energy cooperation, international law has grown and developed into domestic law, either directly or indirectly. For example, states have voluntarily bound to over 500 multilateral environmental

\footnotetext{
$72 \quad$ Stuart Bruce., Op. Cit., page.6

73 For more detail read Rahmat Pramono. (2011). "Ketahanan Pangan dan Energi: Peluang Diplomasi Indonesia Dalam Kerangka ASEAN", Jurnal Diplomasi Kementerian Luar Negeri Republik Indonesia, 3(3).
}

treaties, even treaties giving the obligations on countries to undertake collective action in solving problems of cross-border environmental impact. ${ }^{74}$ These treaties subtly have uncovered sovereign borders and bind the country with a number of obligations. The state also has received and bound to a number of treaties in the fields of economy and trade as well as affect the structure of domestic law. The effect of these treaties was also felt in the field of regulation of fossil-based energy regulatory use of nuclear energy. A number of developments had demonstrated a paradigm shift of natural resources management, albeit in a slow and gradual but it definitely changes can be felt.

In the sector of energy, as stated earlier, management and utilization of energy by countries are also affected by a number of international obligations. If campaigns on the use of renewable energy to the obligations that apply on an international scale, consequently the state to be bound by those obligations, including in the domestic level, countries have to change their national policies in the field of energy even to the selection of energy sources in the development of energy resources and reviewing reset back all the international cooperation which they have agreed. Although no one special instrument which is binding, related to renewable energy resources, but some conventions that are more binding indirectly intersect with the terms of renewable energy, for example in the UNFCCC and the Kyoto Protocol. ${ }^{75}$

\footnotetext{
74 Ivar Baste, et. al. (2012). "Global Responses", Global Environment Outlook 5: Environment for the Future We Want, United Nations Environment Programme, page. 457.

75 See Marco Citelli, et. al, Op. cit., page. 8.
} 
Provisions of the UNFCCC related to renewable energy contained in Article 4 paragraph 1 (b) and (f), which explicitly ask the participating countries to control exhaust emissions of GHG anthropogenic, and mitigation in the context of climate change, including encouraging initiatives to develop the policy into sector economic, social and environmental. Furthermore, the provisions of the Kyoto Protocol related to renewable energy, contained in the provisions of Article 6 (Joint Implementation) and Article 12 (Clean Development Mechanism). Both of these provisions require that states do more effort by using the "flexibility mechanisms" in the development of its energy. ${ }^{76}$

Some of fulfillment of obligations in international regulations concerning the use of renewable energy is indirectly reduce the sovereignty of the country, especially in terms of energy resources, it is certainly feared could be a barrier in the application of the provisions concerning the utilization of renewable energy sources at the international level.

\section{Energy Security}

Energy security is important issues and global event, especially since the oil shock in $1973 .{ }^{77}$ Subsequently, the oil shock also prompted the establishment of the Interna

\section{Ibid}

77 Oil shock price atau oil crisis occurs between October 1973 until Januari 1974. At that time, the world oil price is rise to four fold. This crisis at all once ended the ten years' era cheap energy. It is exacerbated by the economics difficult faced by the industrial countries, bringing force the developing countries to finance energy import through foreign allowance, and resulting a large surplus for the oil exporting countries, particularly Arabic dan OPEC's countries. For more read 1973-1974 Oil Crisis on http://bancroft.berkeley.edu/ROHO/projects/debt/oilcrisis.html. tional Energy Agency, which later formed the obligation forming energy security, especially for its member countries. Definition of energy security in general is a condition where the public need for energy can be met in a sustainable manner based on the principles of availability, affordability (accessibility), and acceptability (quality and price). ${ }^{78}$ To that end, efforts to create energy security need support to access or energy sources as well as the process of conversion and distribution of energy needed to guarantee energy security in the context of the survival of the country in the short- and long term. ${ }^{79}$ Correspondingly, Adrian Bradbrook suggests that energy security is closely related to the three main issues, i.e reducing dependence on oil imports, price stability and a reliable energy supply. ${ }^{80}$

An energy expert Daniel Yergin, provide a definition that energy security can be seen by the interests of the two types of countries, namely exporters and importers. For exporting countries, energy security is to secure energy demand for the products that they have to ensure the necessary financial income countries. Examples of exporting countries are Saudi Arabia as the largest petroleum exporting country in the world. Yergin also divide the importing countries into developed and developing countries. For developed importing countries, such as USA, EU and Japan, ensuring energy security through diversification of energy do as well as trade and investment in energy-producing

\footnotetext{
78 Rahmat Pramono, Op.Cit. page 73.

79 Ibid. 74.

80 Donald N. Zillman, et. al., (eds), Beyond the Carbon Economy: Energy Law in Transition, Oxford: Oxford University Press, 2008, in Stuart Bruce, Op. Cit. page. 9.
} 
region of the world, such as Middle East and North Africa. For developing importing countries, such as Indonesia, energy security is maintained by finding the right solution in addressing the energy changes that will impact on their economies. Developing countries are very concerned with volatility in global energy prices because these issues affect their social and domestic. ${ }^{81}$

Energy security is an important issue in the utilization of renewable energy, especially in terms of maintaining the affordability and availability. As we know, investment in renewable energy development, especially in the sea is full of technology investment, so it requires a large capital investment. Large capital investments would be so related to the price that must be paid by the citizens to get the energy. These factors may affect the affordability and availability the use of renewable energy.

Learning from Europe in developing a policy for securing energy security in its region, to develop the provision on the arrangement of renewable energy, especially marine energy, required international cooperation and investment in a large scale. Not only that, the structure of energy policy worldwide today is already well established and form the world's energy trading system will be an obstacle that is difficult to penetrate. The policy of renewable energy use will get obstacles mainly from fossil-based energy exporting countries, including from companies that have invested heavily in the field of fossil-based energy.

These conditions certainly are a challenge for international law, especially since up to this day still felt inadequate international legal arrangements governing the use of renewable energy. International law should be able to provide answers and certainty of the rules relating to energy security, renewable resources. Those rules should be able to provide a guarantee of access or energy sources as well as the process of conversion and distribution of energy needed to guarantee energy security in the context of the survival of the country in the short- and long term.

\section{CONCLUSION}

Energy is one of the most important aspects in the human life. Along with the increasing human needs for energy with attention to the preservation of nature, it is necessary to develop alternative energy sources that are environmentally friendly; one way is to develop renewable energy. The development of renewable energy is unavoidable as a consequence of the depletion of the world's energy reserves and the further degradation of the environment due to the exploitation and exploration of energy (fossil-based energy).

The presence of renewable energy development activities is undertaken by the countries further demanded international law to actively engage regulate such activity. International law must be able to provide rules that can bring order among the countries in the energy development activities, especially in energy diversification and renewable energy demands of international legal experts to develop rules to keep abreast of evolving technology today.

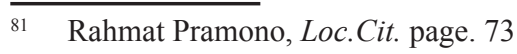


The present, despite a number of provisions related to renewable energy is still limited, but optimistically we can see that countries is slowly begin to take into account the renewable energy in their energy mix policy. The arrangement of renewable energy is starting to look not only at the international level, but also at the regional level. International law must ensure that the utilization of renewable energy is implemented in accordance with the principles developed at this time in the international sphere, in particular the principle of absolute sovereignty over natural resources and sustainable development.

\section{BIBLIOGRAPHY}

Abdelkader Allali et. al. (eds). (2007). Climate Change 2007: Synthesis Report. UK: Cambridge University Press.

Abu Dhabi International Renewable Energy Conference (ADIREC) held on January 15-17, 2013.

Adrian J. Bradbrook et. al. (2005). The Law of Energy for Sustainable Development, IUCN Academy of Environmental Law Research Studies, UK: Cambridge University Press.

Beijing International Renewable Energy Conference (BIREC) held on Nov 7-8, 2005.

C.P. McMullen and J. Jabbour. (2009). "Climate Change Science Compendium" Available online from: http:// www.unep.org/pdf/ccScienceCompendium2009/cc ScienceCompendium2009 full en.pdf, accessed on 14 March 2015, at. 19.40.

Crawford. (2012). Brownlie's Principles of
Public International Law. UK: Oxford University Press, $8^{\text {th }}$ editions.

David Leary and Miguel Esteban. (2009). "Climate Change and Renewable Energy from the Ocean and Tides: Calming the Sea of Regulatory Uncertainty" Marine and Coastal Law, 24: 617-631.

Delhi International Renewable Energy Conference (DIREC) held on October 2729, 2010.

Donald N. Zillman, et. al., (eds). (2008). Beyond the Carbon Economy: Energy Law in Transition, Oxford: Oxford University Press.

Duncan French. (2005). International Law and Policy of Sustainable Development, UK: Juris and Manchester University Press.

Energy Charter Secretariat, "The Energy Charter Treaty and Related Documents." Accessed on website: http:// www.encharter.org/fileadmin/user upload/document/EN.pdf Accessed on 26 March 2014), page. 19

EU Renewable Energy Directive, document 2009/28/EC.

Final Act Energy Charter Treaty.

International Energy Agency. "Energy for All: Financing for the Poor, " October 2011. The document downloadable on: http://www.iea.org/papers/2011/ weo2011 energy for all.pdf

International Energy Agency. "World Energy Outlook 2011, ” page. 39. Available online at: http://www.iea.org/publications/freepublications/publication/ weo2011_web.pdf.

International Energy Agency. World Energy Outlook 2011, available on- 
line at: https://www.iea.org/publications/freepublications/publication/ WEO2011_WEB.pdf, accessed on 10 March 2015, at 20.22.

Ivar Baste, et. al. (2012). "Global Responses", Global Environment Outlook 5: Environment for the Future We Want, United Nations Environment Programme.

Janet L. Sawin, Mainstreaming Renewable Energy in 21st Century, World Watch Paper, 2004, downloadable on: http:// www.worldwatch.org/system/files/ EWP169.pdf.1

Johannesburg Plan, UN Doc A/CONF. $199 / 20$.

John O'Brien. (2001). International Law. London: Cavendish Publishing Limited.

Joseph F.C. Di Mento. (2003). The Global Environment and International Law. USA: The University of Texas Press.

Karen E. Makuch \& Ricardo Pereira (Ed.). (2012). Environmental and Energy Law. UK: Blackwell Publishing Ltd.

Kyoto Protokol 1997.

Marco Citelli, Marco Barassi, Ksenia Belykh. (2014). "Renewable Energy in International Arena: Legal Aspects and Cooperation", Groningen Journal of International Law, 2(1).

Patricia Park. (2013). International Law for
Energy and the Environment, $2^{\text {nd }}$ edition, Boca Raton US: CRC Press.

Protocol on Energy Efficiency. Document downloadable on: www.encharter.org/ fileadmin/user upload/...texts/1994 PEEREA.pdf

Rahmat Pramono. (2011). "Ketahanan Pangan dan Energi: Peluang Diplomasi Indonesia Dalam Kerangka ASEAN", Jurnal Diplomasi Kementerian Luar Negeri Republik Indonesia, 3(3).

Saleh Mothana Obadi and Matej Kortek. (2012). "The Analysis of Natural Gas and Crude Oil Market from the Global and EU Perspective", Studia Commercialia Bratislavensia Journal, 5(18).

Stuart Bruce. (2013). "International Law And Renewable Energy: Facilitating Sustainable Energy For All?", Melbourne Journal of International Law, 14.

UN General Assembly Resolution 65/151 "International Year of Sustainable Energy for All" Available online at: http://www.un.org/ga/search/view doc.asp?symbol=A/RES/65/151

UNGA Res. No. 65/151 "International Year of Sustainable Energy for All”.

Washington International Renewable Energy Conference (WIREC) held on March 3-6, 2008. 